\title{
KATEGÓRIÁKBA SOROLÁS A CSŐTÁVVEZETÉKEK ÉLETTARTAM-MENEDZSELÉSÉBEN
}

\begin{abstract}
Harmati István
Az élettartam menedzselés szénhidrogénszállító csőtávvezetékek esetében azon szulkséges és elégséges módszerek összegyüjtését és kidolgozását jjelenti, amelyekkel a vezetékek állapotmegítélése, rehabilitációja egységes rendszerben kezelhető. Ebben a rendszerben a vezetékek kategóriákba sorolása fontos szerephez jut azáltal, hogy lehetőséget nyújt az ugrásszerủen megnovekedett információmennyiség feldolgozására, továbbá a vezetékek kőzötti különbségek visszatükrözésére.
\end{abstract}

\section{Bevezetés}

A szénhidrogénszállító csőtávvezetékek kategóriákba sorolását mindenek előtt a biztonságos és gazdaságos üzemeltethetöség indokolja, így a kategóriákbasorolás céljai ebböl adódóan az alábbiak:

1. a vezetékek globális ill. lokális állapotának megítélése, ennek segítségével a vezeték minősítése;

2. a vezeték állapotváltozásainak legalább részleges, ugyanakkor periodikus nyomon követése;

3. a vezeték felülvizsgálati periódusának és módjának kijelölése;

4. segítségnyújtás a vezetéken történő beavatkozások módjának és jellegének meghatározásához, illetve megtervezéséhez és következményeinek megítéléséhez [1].

A British Gas-al való együttmüködés eredményeképpen a magyarországi üzemeltető (MOL Rt. KFÜ) is meghonosított fejlett roncsolásmentes vizsgálati módszereket a vezetékek állapotmegítélésére. Ezek közül elsősorban az intelligens csögörényezés az, amely igen sok információt nyújt a vezeték állapotáról.

Az üzemeltetö rendelkezésére álló megnövekedett információtömeg és a csővezetékek felülvizsgálatának és karbantartásának jelenlegi gyakorlata között ma még nincs teljes összhang. Ezen ellentmondás feloldására az üzemeltető szakemberei már több müszakilag megalapozott intézkedést is tettek, azonban a probléma végleges megoldását egy átfogó információs rendszer gyakorlati bevezetése jelentené. 


\section{A kategóriákba sorolás elméleti alapjai}

A magyarországi szénhidrogénszállító csőtávvezetékek kategóriákba sorolásának elméletét - elemezve más számszerüsítési törekvéseket [2], [3] - a Miskolci Egyetem Mechanikai Technológiai Tanszékén a MOL Rt. megbízásából dolgozták ki a Csővezetékek minősítésének általános rendszere témájú $\mathrm{K}+\mathrm{F}$ munka keretében [1]. Az alábbiakban egy rövid elméleti összefoglaló található a kategóriákba sorolásról

A csőtávvezetékek kategóriákba sorolásának szempontjai úgy vannak kialakítva, hogy messzemenöen figyelembe vegyék a magyarországi üzemeltetési viszonyokat. A szempontok két fỏ csoportba sorolhatók attól függően, hogy a törés bekövetkezésének valószínűségére vagy a törés következményeire vonatkoznak. A szempontokon belül további összetevők képezik a kiértékelés alapját.

Az összetevők között vannak olyanok, melyek megítélése szubjektív, vagyis az adott összetevőt - ilyen pl. a mozgási lehetőségek, veszélyek - nem egy konkrét számérték alapján, hanem tapasztalati úton ítéljük meg. Ezek az összetevők azért igen jelentősek, mert a legnehezebben számszerủsíthető tudást, az üzemeltetői tapasztalatot veszik figyelembe. Az összetevők nagyobb része számszerüsíthető, így ezek kiértékelése az adott összetevőnek megfelelő határértékekkel való összehasonlítással történik. A szempontok és összetevőik csoportosítása az 1. ábrán látható [4]. A számszerüsíthető összetevők jellemző mérőszámának meghatározására a következő általános összefüggés adható:

$$
X y_{j}=\sum_{i=1}^{n} k_{l i} \cdot \frac{Z_{i}}{7}
$$

ahol: $\quad \mathrm{Xy}_{\mathrm{j}} \quad$ az összetevőre jellemző mérőszám,

X szempont föcsoport (A vagy B),

y szempont alcsoport (a vagy b vagy c),

j az összetevő sorszáma az alcsoporton belül (1 - 8),

n az összetevő alkotóinak száma,

i az összetevő alkotójának sorszáma,

1 az összetevö sorszáma (1 - 21),

$\mathrm{k}_{\text {li }} \quad$ az I -edik összetevő $\mathrm{i}$-edik alkotójának súlyozási tényezője,

$Z_{i} \quad$ az összetevő i -edik alkotójának értéke,

Z az összetevő alkotóinak összege. 


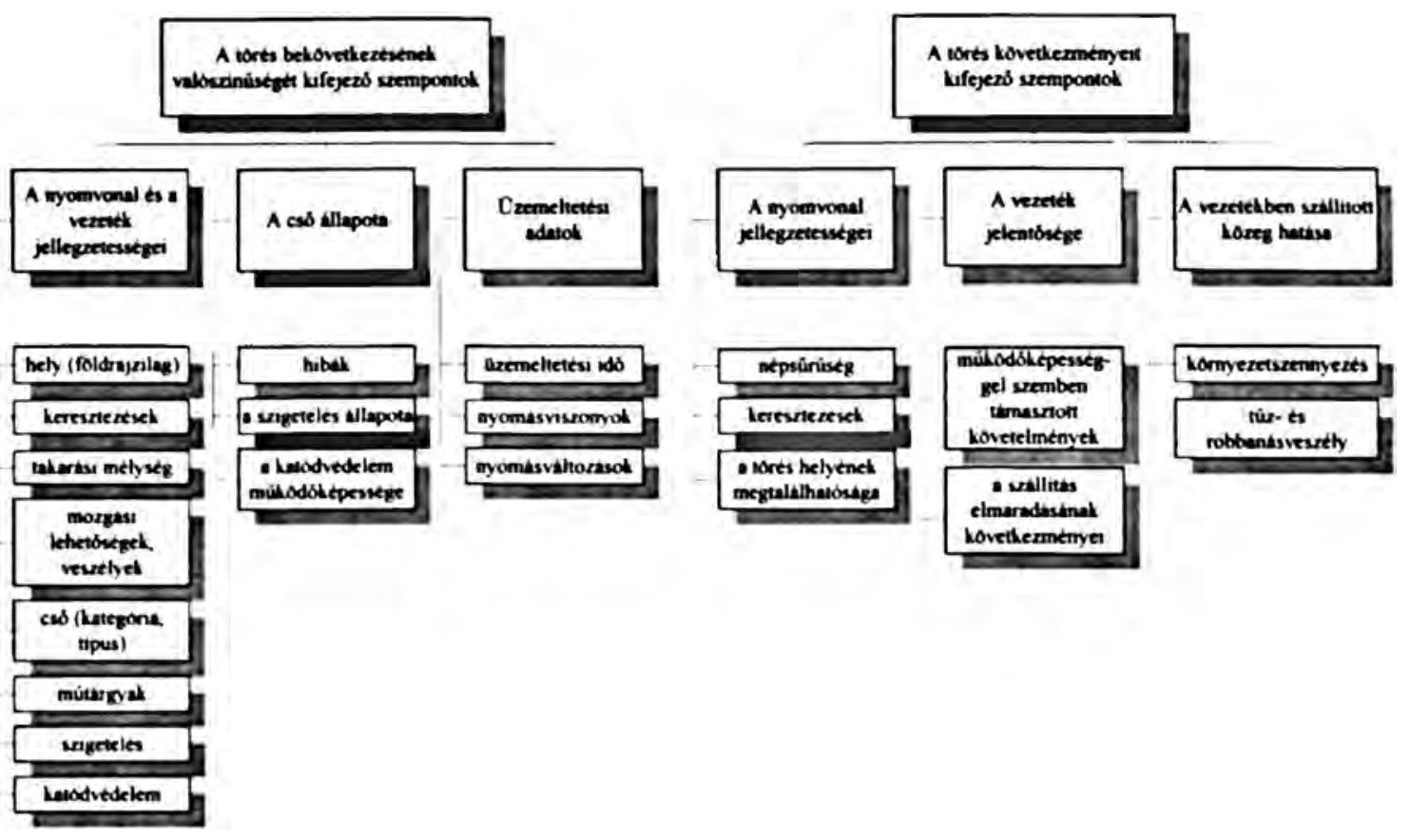

1. ábra

A kategóriákba sorolás szempontjai

Az összetevő hatása

(i) kicsi, ha $X y_{j}<h_{l a}$;

(ii) közepes, ha $\mathrm{h}_{\mathrm{la}}<\mathrm{Xy}_{\mathrm{j}}<\mathrm{h}_{\mathrm{lf}}$ :

(iii) nagy, ha $X y_{j}>h_{l f}$

ahol: $h_{1 \mathrm{a}}$ és $h_{1 f}$ az 1 -edik összetevőnek megfelelő alsó és felső határérték. Ez alól kivételt képez a hibák összegzett hatásának megítélése a törés bekövetkezésének valószínüségére, amelyre a következõ összefüggés érvényes:

$$
A b_{1 q}=k_{91} \cdot \frac{H_{111}}{H_{q}}+k_{92} \cdot \frac{H_{2 q}}{H_{q}}+k_{93} \cdot \frac{H_{3 q}}{H_{q}}
$$

ahol $\quad \mathrm{Ab}_{1 \mathrm{q}}$ a q -adik hibaosztály dimenzió nélküli mérőszáma,

$\mathrm{H}_{\mathrm{lq}}$ a nagy veszélyességü hibák száma a q-adik hibaosztályban,

$\mathrm{H}_{2 \mathrm{q}} \quad$ a közepes veszéléyességü hibák száma a q-adik hibaosztályban,

$\mathrm{H}_{3 q} \quad$ a kis veszéléyességü hibák száma a q-adik hibaosztályban,

$\mathrm{H}_{\mathrm{q}} \quad$ az összes hibák száma a q-adik hibaosztályban,

$\mathrm{k}_{9 \mathrm{z}} \quad$ a hibák veszélyességét minősítő tényező. 
A hibák hatása a q-adik hibaosztályban

(i) kicsi, ha

$$
\begin{aligned}
& A b_{1 q}<h_{9 a} \text { és } H_{1 q}=0 \\
& A b_{1 q}<h_{9 a} \text { és } H_{1 q}<0.02 H_{q} \text { vagy } \\
& h_{9 a}<A b_{1 q}<h_{9 f} \text { és } H_{1 q}<0.01 H_{q} ; \\
& A b_{1 q}<h_{9 a} \text { és } H_{1 q}>0.02 H_{q} \text { vagy } \\
& h_{9 a}<A b_{1 q}<h_{9 f} \text { és } H_{1 q} \geq 0.01 H_{q} \text { vagy } \\
& A b_{1 q}>h_{9 a}
\end{aligned}
$$

(ii) közepes, ha

(iii) nagy, ha

A hibák összegzett hatása

(i) kicsi, ha a hatás minden hibaosztályban kicsi;

(ii) közepes, ha a hatás legalább egy hibaosztályban közepes, de egyetlen hibaosztályban sem nagy;

(iii) nagy, ha a hatás legalább egy hibaosztályban nagy.

A csővezetékek állapotának végső megítélésére az összetevők kiértékelése után kerülhet sor. Attól függöen, hogy milyen arányban szerepelnek kis, közepes illetve nagy veszélyességü összetevők a vezetékeket öt különbözỏ kategóriába lehet sorolni: különösen veszélyes, fokozottan veszélyes, közepesen veszélyes, kevésbé veszélyes és alig veszélyes.

\section{Irodalomjegyzék}

[1] Csővezetékek minősítésének általános rendszere, II. melléklet: Vezetékek (vezetékszakaszok) kategóriákba (osztályokba) sorolása. ME Mechanikai Technológiai Tanszék EK 5930055, 1994. Témavezetö: Dr. Török Imre.

[2] Code of practice for carrying out on line inspection of gas transmission systems. British Gas engineering standard BGC/ PS/OLI 1. May 1983.

[3] MUHLBAUER, W. K.: A proactive approach to pipe line risk assessment. Pipe Line Industry, July 1992. p. 29-32.

[4] HARMATI, I.: Categorisation of hydro-carbon transporting pipelines. MsC thesis. 1995. p. 1-90.

Harmati István doktorjelölt

Miskolci Egyetem/Miskolc Egyetemváros 3515

Tel: 46/366-111 (17-90) 